\title{
Chemical composition of polyphenols extracted from strawberry pomace and their effect on physiological properties of diets supplemented with different types of dietary fibre in rats
}

\author{
Monika Kosmala $\cdot$ Zenon Zduńczyk • \\ Krzysztof Kołodziejczyk • Elżbieta Klimczak • \\ Jerzy Juśkiewicz • Przemysław Zduńczyk
}

Received: 24 April 2013/Accepted: 30 June 2013/Published online: 12 July 2013

(C) The Author(s) 2013. This article is published with open access at Springerlink.com

\begin{abstract}
Purpose The objective of this study was to establish the composition of polyphenolic preparations obtained from industrial strawberry pomace with two methods of extraction: the water and the water-alcoholic one and then to analyse their effects in the gastrointestinal tract depending on the composition of dietary fibre-cellulose or fructooligosaccharides (FOS).

Methods Freeze-dried water extract (PTW), containing $5.1 \%$ of ellagic acid, $0.2 \%$ of proanthocyanidins, and soluble carbohydrates as a major part, and water-alcohol extract (PTE), containing $17.1 \%$ of ellagic acid and $10.9 \%$ of proanthocyanidins, were administered, in the equivalent quantity of $0.06 \%$ of ellagic acid, to 4- to 8 -week-old rats ( 8 animals per group), as a component of modified AIN-93 diets containing $5 \%$ of cellulose or FOS. Results The addition of strawberry pomace extracts had no effect on either the diet intake or the body weight of experimental rats. Both extracts, similarly to FOS, beneficially reduced the activity of $\beta$-glucuronidase in caecal digesta, with the PTW effect being significantly higher than that of PTE (7.59 vs. $9.20 \mu \mathrm{mol} / \mathrm{h} / \mathrm{g}, P=0.001)$. In comparison with PTE, the PTW extract significantly increased the caecal digesta mass ( 1.45 vs. $1.27 \mathrm{k} / \mathrm{kg} \mathrm{BW})$ and the total production of SCFA ( 86.1 vs. $71.4 \mu \mathrm{mol} / 100 \mathrm{~g} \mathrm{BW})$. The extract enhanced the physiological effect of FOS by
\end{abstract}

\footnotetext{
M. Kosmala ( $₫) \cdot$ K. Kołodziejczyk · E. Klimczak Institute of Chemical Technology of Food, Lodz University of Technology, ul. B. Stefanowskiego 4/10, 90-924 Lodz, Poland e-mail: monika.kosmala@p.lodz.pl

Z. Zduńczyk · J. Juśkiewicz · P. Zduńczyk

Division of Food Science, Institute of Animal Reproduction and Food Research, Polish Academy of Sciences, ul. Tuwima 10, 10-747 Olsztyn, Poland
}

inhibiting the activity of $\beta$-glucuronidase, increasing the caecal digesta mass and SCFA production. Such an effect was not recorded in the case of the PTE preparation.

Conclusions The addition of strawberry pomace extracts affected the activity of certain enzymes of intestinal microflora and its most important products.

Keywords Ellagitannins · Ellagic acid ·

Proanthocyanidins $\cdot$ Strawberry pomace

$\begin{array}{ll}\text { Abbreviations } \\ \mathrm{C}_{\mathrm{C}} & \begin{array}{l}\text { Control diet with cellulose } \\ \text { Control diet with fructooligosaccharides }\end{array} \\ \mathrm{C}_{\mathrm{FOS}} & \begin{array}{l}\text { Fructooligosaccharides } \\ \text { FOS }\end{array} \\ \text { PTE } & \begin{array}{l}\text { Strawberry polyphenols ethanol extract } \\ \text { PTE }\end{array} \\ & \begin{array}{l}\text { Diet with strawberry polyphenols ethanol } \\ \text { extract with cellulose }\end{array} \\ \text { PTE }_{\mathrm{FOS}} & \begin{array}{l}\text { Diet with strawberry polyphenols ethanol } \\ \text { extract with fructooligosaccharides }\end{array} \\ \text { PTW } & \begin{array}{l}\text { Strawberry polyphenols water extract } \\ \text { PTW }\end{array} \\ & \begin{array}{l}\text { Diet with strawberry polyphenols water extract } \\ \text { with cellulose }\end{array} \\ \text { PTW } & \begin{array}{l}\text { Diet with strawberry polyphenols water extract } \\ \text { with fructooligosaccharides }\end{array} \\ \text { SCFAs } & \text { Short-chain fatty acids }\end{array}$

\section{Introduction}

One of the important elements of health prophylaxis in economically developed countries is the increase in the consumption of vegetables and fruit being the source of biologically active dietary components that have a beneficial influence on human health [1]. An additional source of 
these compounds in diet might be by-products of plant food processing [2], including fruit pomace, e.g. of strawberry.

In a number of countries, the harvest season of strawberry is short and during the industrial production of juices a considerable amount of biologically active components remains in fruit pomace. This still underestimated byproduct may constitute a source of health-promoting substances, particularly dietary fibre and polyphenols [3, 4]. One of the possibilities is to use strawberry seeds (achenes) in the production of gluten-free bread with an increased content of dietary fibre and polyphenols [5]. Another possibility, particularly advisable in the case of an increased content of sand and physical impurities in pomace, is the extraction of biologically active components, polyphenols in particular [6]. Due to the application of enzymes degrading polysaccharides of the cell walls of the processed fruit, the composition of polyphenols may differ from that of fruit, and these compounds may be more easily extracted with various solvents $[7,8]$.

Strawberry polyphenols, mainly ellagitannins and ellagic acid, demonstrate a wide spectrum of positive effects on human health [9], primarily due to antioxidant [10, 11], anti-carcinogenic [12], anti-inflammatory and anti-neurogenerative $[13,14]$ effects. Such properties are exhibited by polyphenol metabolites present in blood after the digestion process of polyphenols as well as after their metabolism in the gastrointestinal tract and liver [15].

Products of ellagitannins hydrolysis and metabolism in the gastrointestinal tract are derivatives of hydroxy- $6 \mathrm{H}-$ dibenzopyran-6-one defined as urolithin $\mathrm{A}$ and $\mathrm{B}$, which are glucuronidated and sulphated in the intestinal-liver circulation, then participate in the metabolic process and are also excreted with faeces and urine [12, 16, 17]. Results of a research on ellagitannins and ellagic acid bioavailability and metabolism prove that these substances and their derivatives might occur in the digestive system in considerable concentrations as products of digestion with own enzymes, particularly with these of the large intestine [16]. Metabolism of ellagitannins is dependent on individual colonic microflora, high or low production of urolithins can occur [18]. Different urolithin hydroxylation patterns were observed for different animal species, suggesting that the microbiota responsible for the metabolism of ellagitannins in each animal species produces dehydroxylases for the removal of specific hydroxyls from the ellagic acid residue [19]. Glucuronide and sulphatic derivatives (sulphates) of urolithins transported with blood may have a beneficial effect on the level and proportions of cholesterol fractions [20, 21], may decrease the blood level of lipids [22] and influence remote organs [21] and have effects in the vascular inflammation [23].

Biodiversity and physiological effects of polyphenols are known to depend on their solubility determined by the chemical structure and the size of molecules as well as by links with other compounds, mainly fibre [13]. Diversified intensiveness of the fermentation processes in the intestines, determined by the composition and physiochemical properties of dietary fibre, might constitute an additional factor in this respect [24]. In this context, interesting from both cognitive and practical perspective are the two following issues: what is the composition of preparations of polyphenols that may be obtained from strawberry pomace with simple extraction methods, and what is the effect of the content and properties of dietary fibre on the physiological properties of these compounds.

The objective of the presented study was to examine the composition of water and water-ethanol extracts obtained from industrial strawberry pomace as well as to broaden knowledge on the physiological effects of polyphenols of these extracts in the gastrointestinal tract depending on the composition of dietary fibre, i.e. contents of sparingly fermentable cellulose and easily fermentable fructooligosaccharides.

\section{Materials and methods}

\section{Materials}

Water and ethanol strawberry extracts were obtained from industrial strawberry pomace produced on a modern production line for concentrated fruit juices at the ALPEX Company (Łęczeszyce, Poland). To this end, $10 \mathrm{~kg}$ of fresh pomace collected from the production line was dried in a convection dryer $(1.6 \mathrm{~kW}$ KC-100/200, WAMiE, Warsaw, Poland) at the temperature $65-70{ }^{\circ} \mathrm{C}$ for $8 \mathrm{~h}$. The dried material $(4.9 \mathrm{~kg})$ was passed through sieves with 2 - and 5-mm mesh diameter using an Analysette 3 sifter (Fritsch, Idar-Obersten, Germany). Fractions with particle sizes over $5 \mathrm{~mm}$ were ground on a universal grinding machine NMK110 (Spomasz, Nakło, Poland); next, the grounded material was once more passed through two sieves. The material with particle sizes between 2 and $5 \mathrm{~mm}$ and the weight of $1.66 \mathrm{~kg}$ constituted part of pomace devoid of seeds (achenes) and was used for successive production of water and ethanol extracts applied in the present study. The composition of pomace (seedless $2-5 \mathrm{~mm}$ fraction) on dry matter basis was as follows: total carbohydrates $69 \%$, protein $21 \%$, ash $8 \%$, including $6 \%$ sand; fat $5.5 \%$, polyphenols $3.9 \%$, including $2.4 \%$ proanthocyanidins; $1.5 \%$ free ellagic acid and its derivatives in the form of ellagitannins; $0.11 \%$ flavonols and $0.09 \%$ anthocyanins. The water extract was produced with the use of $1,500 \mathrm{~g}$ of dried material with particle size between 2 and $5 \mathrm{~mm}$. Water extraction was conducted three times at the temperature of 65-70 ${ }^{\circ} \mathrm{C}$ for $1 \mathrm{~h}$, at the solvent to material ratio of $4: 1$. 
Next, the extract was each time separated from the pomace in a laboratory screw press with the basket volume of $4 \mathrm{~L}$. The resultant extract was condensed in a vacuum evaporator and next dried in a dryer under the pressure of $40 \mathrm{~mm} \mathrm{Hg}$, at the temperature of $70{ }^{\circ} \mathrm{C}$. The yield of dry water extract (PTW) production amounted to $7.2 \%$ per seedless strawberry pomace.

In order to obtain the water-alcohol extract, $4 \mathrm{~L}$ of $90 \%$ ethanol was added to $3.5 \mathrm{~kg}$ of water-extracted pomace with water content of $59 \%$, which enabled obtaining the solvent to extraction material ratio of $4: 1$ and $60 \%$ concentration of ethanol in the extractant. After $24 \mathrm{~h}$ of extraction at the temperature of $20^{\circ} \mathrm{C}$, the extract was separated from pomace with the laboratory press. Once more, $3.5 \mathrm{~L}$ of $60 \%$ ethanol was added to the pomace, and the sample was left for $24 \mathrm{~h}$. Next, the extract was pressed in the laboratory press. Ethanol was expelled from the two combined extracts. Afterwards, the solution was subject to freeze-drying in a TG 5 lyophilizer (VEB Hochvakuum Dresden, Germany), which enabled obtaining a dry extract of strawberry polyphenols. The yield of ethanol extract (PTE) production amounted to $3.1 \%$ per dry seedless strawberry pomace.

Determination of the composition of strawberry polyphenolic preparations

\section{Basic composition}

Basic composition of extracts was determined with the AOAC methods [25] using the following procedures: protein content-920.152; crude fat-930.09; dry matter and ash content-940.26, total dietary fibre (TDF)-985.29, insoluble dietary fibre (IDF) 991.42, respectively. Soluble dietary fibre was calculated as a difference between TDF and IDF. Simple sugars, sorbitol and sucrose were determined as described previously [4] by boiling extraction with $0.02 \mathrm{~mol} / \mathrm{L} \mathrm{CaCO}_{3}$, filtration and desalination in an anion exchange column (two parts of Amberlite IRA 400 anion exchanger to one part of Amberlite IR 120 cation exchanger) and analysis in a Knauer HPLC set (Berlin, Germany) with an RI detector and a Bio-Rad Aminex HPX-87C column, $300 \times 7.8 \mathrm{~mm}$ (Phenomenex, Torrance, $\mathrm{CA}$, USA), with the flow rate of $0.5 \mathrm{~mL} / \mathrm{min}$, at the temperature of $85{ }^{\circ} \mathrm{C}$. Glucose, fructose, sucrose and sorbitol (Sigma-Aldrich, St Louis, MO, USA) were used as standards.

\section{Determination of polyphenols with the HPLC method}

The extraction was conducted as described previously [4], 3 times with $70 \%$ methanol in ultrasounds $(15 \mathrm{~min})$. The extract was analysed with the HPLC method in an HPLC system with a DAD detector (Dionex, Sunnyvale, CA, USA) and with $250 \times 4.60 \mathrm{~mm}$ Gemini $5 \mathrm{u}$ C18 110A column (Phenomenex, Torrance, CA, USA). Phase A consisted of $0.05 \%$ phosphoric acid in water, whereas phase B of $0.05 \%$ phosphoric acid in acetonitrile. The following gradient was applied at the flow rate of $1.25 \mathrm{~mL} / \mathrm{min}$ : 5-min stabilization with $4 \% \mathrm{~B}$, next from 5 to $12.50 \mathrm{~min}$ with $4-15 \% \mathrm{~B}$, from 12.50 to $42.40 \mathrm{~min}$ with $15-40 \% \mathrm{~B}$, from 42.40 to 51.80 min with $40-50 \% \mathrm{~B}$, from 51.80 to 53.40 min with $50 \% \mathrm{~B}$ and from 53.40 to 55 min with $4 \% \mathrm{~B}$. The column's temperature was set at $25^{\circ} \mathrm{C}$.

\section{Identification of polyphenols of strawberry preparations}

The following standards were used for identification: ellagic acid (Extrasynthese, Genay, France), quercetin glucoside (quercetin-3-O-glucopyranoside, Extrasynthese, Genay, France), quercetin galactoside (Extrasynthese, Genay, France), kaempferol glucoside (kaempferol-3-O-glucoside, Extrasynthese, Genay, France), quercetin rhamnoside (Extrasynthese, Genay, France), quercetin (Extrasynthese, Genay, France) and kaempferol (Extrasynthese, Genay, France), at 360-nm wavelength.

Pelargonidin glucoside (Extrasynthese, Genay, France) was determined at the wavelength of $520 \mathrm{~nm}$. The content of catechin and derivatives of coumaric acid were determined based on the measurement of UV-DAD spectrum at $280 \mathrm{~nm}$ and the application of the following standards: catechin (Sigma-Aldrich, St Louis, USA) and p-coumaric acid (Sigma-Aldrich, St Louis, USA). The content of ellagitannins was determined based on the amount of ellagic acid released in standard conditions of acidic hydrolysis [6].

\section{Analysis of proanthocyanidins and free catechins}

Proanthocyanidins of the extracts were determined from lyophilized samples. Proanthocyanidins degradation method in an acidic environment with an overdose of phloroglucinol was used. The method involving the use of phloroglucinolysis reaction was described by Kennedy and Jones [26]. About $20 \mathrm{mg}$ of a powdered sample (pomace or extract) was weighed to a 2-mL Eppendorf tube, and then, $800 \mu \mathrm{L}$ of a methanol solution containing phloroglucinol $(75 \mathrm{~g} / \mathrm{L})$ and ascorbic acid $(15 \mathrm{~g} / \mathrm{L})$ was added to the sample. Phloroglucinolysis reaction was begun by adding $400 \mu \mathrm{L}$ of $0.2 \mathrm{M}$ hydrochloric acid in methanol. The incubation was carried out for $30 \mathrm{~min}$ at the temperature of $50{ }^{\circ} \mathrm{C}$. Next, the samples were instantly cooled down in a bath with ice, and the reaction was stopped by adding $600 \mu \mathrm{L}$ of a $40 \mathrm{mM}$ sodium acetate solution. The samples were next centrifuged for $5 \mathrm{~min}$ at 3,600 $\mathrm{g}$ and then diluted 
twice with a $40 \mathrm{mM}$ sodium acetate solution. Before being injected onto the HPLC system, the sample was stored at the temperature of $4{ }^{\circ} \mathrm{C}$. Products of acidic degradation of polymeric proanthocyanidins were separated with the Knauer Smartline chromatograph (Berlin, Germany) equipped with a UV-Vis P2800 detector (Knauer, Berlin, Germany) and a fluorescent detector (FD) RF-10AXL (Schimadzu, Tokyo, Japan). The separation was conducted on Gemini $5 \mathrm{u} \mathrm{C} 18$ 110A $250 \mathrm{~mm} \times 4.6 \mathrm{~mm}, 5 \mu \mathrm{m}$ column with gradient elution with $2.5 \%$ water solution (v/v) of acetic acid (phase A) and $80 \%(\mathrm{v} / \mathrm{v})$ acetonitrile in water (phase B). The following gradient was used: 0-10 min, 4-7 \% B; 10-27 min, 7-30\% B; 27-29 min, 30-70 \% B; 29-34 min, $70 \% \mathrm{~B}$; 34-35 min, 70-4 \% B; and 35-40 min, $4 \% \mathrm{~B}$. The flow rate amounted to $1 \mathrm{~mL} / \mathrm{min}$, the temperature of separation to $25{ }^{\circ} \mathrm{C}$ and the volume of injection to $20 \mu \mathrm{L}$. The chromatographic data were collected with the use of ClarityChrom programme (Knauer, Berlin, Germany). The identification of components was conducted on the basis of comparing the retention times and UV-Vis spectra of standards of (-)-epicatechin, $(+)$-catechin, (-)-epigallocatechin, adducts: (-)-epigallocatechin-phloroglucinol, (-)-epicatechin-phloroglucinol and (+)-catechin-phloroglucinol. Quantitative analyses of released flavonols, i.e. (+)-catechin and (-)-epicatechin, were conducted on the basis of chromatograms recorded with the FD detector set at 278-nm excitation wavelength and 360-nm emission wavelength. Phloroglucinol adducts were determined on the basis of chromatograms registered with the PDA detector set at $280-\mathrm{nm}$ wavelength. In order to calculate the released ellagitannins, use was made of calibration curves determined for (-)-epicatechin and $(+)$-catechin. In turn, a calibration curve determined for (-)-epicatechin-phloroglucinol adduct was used for adducts. Free (+)-catechin, (-)-epicatechin and (-)-epigallocatechin were determined from extracts as described above.

\section{Rats and diets}

The use of animals was conducted in compliance with European guidelines for the care and use of laboratory animals and was approved by the Ethical Committee for Animal Experiments in the northeast Poland region. The experiment was performed on 48 male Wistar rats aged approximately 4 weeks. The experimental diets were administered for 4 weeks to 8 rats per group housed individually in plexiglas cages.

Diets contained similar contents of protein (from casein supplemented with methionine), fat (soybean oil), minerals and vitamins (from AIN-93G mixtures [27] and a similar content of fibre, however, from different sources, i.e. cel- lulose or fructooligosaccharides (Table 1). The compared polyphenolic preparations were administered in an amount of $1.13 \%\left(\mathrm{PTW}_{\mathrm{C}}\right.$ and $\left.\mathrm{PTW}_{\mathrm{FOs}}\right)$ and $0.37 \%\left(\mathrm{PTE}_{\mathrm{C}}\right.$ and $\mathrm{PTE}_{\mathrm{FOS}}$ ) of the feed air-dried, which constitutes $0.06 \%$ of the total ellagic acid in a diet as the basic active substance of strawberries according to the current state of knowledge [12, 13, 21]. Experimental diets and tap water were administered ad libitum. The animals were maintained under standard conditions: temperature of $21-22{ }^{\circ} \mathrm{C}$ and relative air humidity of $50-70 \%$, intensive ventilation of rooms $(15 \times / \mathrm{h})$ and $12-\mathrm{h}$ lighting. Individual body weights and food intakes were recorded.

Table 1 Composition of experimental diets, \%

\begin{tabular}{|c|c|c|c|c|c|c|}
\hline \multirow[t]{2}{*}{ Component } & \multicolumn{6}{|c|}{ Experimental group } \\
\hline & $\mathrm{C}_{\mathrm{C}}$ & $\mathrm{C}_{\mathrm{FOS}}$ & $\mathrm{PTW}_{\mathrm{C}}$ & PTW $_{\text {FOS }}$ & $\mathrm{PTE}_{\mathrm{C}}$ & $\mathrm{PTE}_{\mathrm{FOS}}$ \\
\hline Casein & 14.0 & 14.0 & 14.0 & 14.0 & 14.0 & 14.0 \\
\hline Methionine & 0.2 & 0.2 & 0.2 & 0.2 & 0.2 & 0.2 \\
\hline Soybean protein & 1.9 & 1.9 & 1.77 & 1.77 & 1.83 & 1.83 \\
\hline Soybean oil & 8.0 & 8.0 & 8.0 & 8.0 & 8.0 & 8.0 \\
\hline Cellulose & 5.0 & - & 5.0 & - & 5.0 & - \\
\hline FOS & - & 5.0 & - & 5.0 & - & 5.0 \\
\hline Extract $\mathrm{PTW}^{\mathrm{a}}$ & - & - & 1.13 & 1.13 & - & - \\
\hline Extract $\mathrm{PTE}^{\mathrm{b}}$ & - & - & - & - & 0.37 & 0.37 \\
\hline Cholesterol & 0.5 & 0.5 & 0.5 & 0.5 & 0.50 & 0.5 \\
\hline Minerals $^{\mathrm{c}}$ & 3.5 & 3.5 & 3.5 & 3.5 & 3.50 & 3.5 \\
\hline Vitamins $^{\mathrm{d}}$ & 1.0 & 1.0 & 1.0 & 1.0 & 1.00 & 1.0 \\
\hline Fructose & 60.0 & 60.0 & 60.0 & 60.0 & 60.00 & 60.0 \\
\hline Maize starch & 5.9 & 5.9 & 5.9 & 5.9 & 5.6 & 5.6 \\
\hline
\end{tabular}

${ }^{a}$ Strawberry polyphenols extracted with water

b Strawberry polyphenols extracted with ethanol

c AIN-93G [27], per kg mix, g: calcium carbonate anhydrous $(40.04 \% \mathrm{Ca}) 357$, potassium phosphate monobasic $(22.76 \% \mathrm{P}$, $28.73 \%$ K) 196 , potassium citrate and tripotassium monohydrate $(36.16 \% \mathrm{~K}) 70.78$, sodium chloride $(39.34 \% \mathrm{Na}, 60.66 \% \mathrm{Cl}) 74$, potassium sulphate $(44.87 \% \mathrm{~K}, 18.39 \% \mathrm{~S}) 46.6$, magnesium oxide $(60.32 \% \mathrm{Mg}) 24$, ferric citrate $(16.5 \% \mathrm{Fe}) 6.06$, zinc carbonate $(52.14 \% \mathrm{Zn}) 1.65$, sodium meta-silicate $\times 9 \mathrm{H}_{2} \mathrm{O}(9.88 \% \mathrm{Si}) 1.45$, manganous carbonate $(47.79 \% \mathrm{Mn}) 0.63$, cupric carbonate $(57.47 \%$ $\mathrm{Cu}) 0.3$, powdered sucrose 221.026 , chromium potassium sulphate $\times 12 \mathrm{H}_{2} \mathrm{O}(10.42 \% \mathrm{Cr}) 0.275$; mg: boric acid $(17.5 \% \mathrm{~B}) 81.5$, sodium fluoride $(45.24 \% \mathrm{~F}) 63.5$, nickel carbonate $(45 \% \mathrm{Ni}) 31.8$, lithium chloride $(16.38 \% \mathrm{Li}) \quad 17.4$, sodium selenate anhydrous $(41.79 \% \mathrm{Se}) 10.25$, potassium iodate $(59.3 \%$ I) 10 , ammonium paramolybdate $\times 4 \mathrm{H}_{2} \mathrm{O}(54.34 \% \mathrm{Mo}) 7.95$, ammonium vanadate (43.55\% V) 6.6

d AIN-93G [27], g/kg mix: nicotinic acid 3.0, Ca pantothenate 1.6, pyridoxine- $\mathrm{HCl} 0.7$, thiamin- $\mathrm{HCl} 0.6$, powdered sucrose 974.655 , riboflavin 0.6 , folic acid 0.2 , biotin 0.02 , vit. $\mathrm{B}_{12}$ (cyanocobalamin, $0.1 \%$ in mannitol) $2.5 ; \mathrm{IU} / \mathrm{g}$ : vit. E (all-rac- $\alpha$-tocopheryl acetate, 500 ) 15.0 , vit. A (all-trans-retinyl palmitate, 500000) 0.8 , vit. $\mathrm{D}_{3}$ (cholecalciferol, 400000) 0.25 , vit. K-1 (phylloquinone) 0.075 
Sample collection and analysis

During 4 weeks of experiment, faeces were collected and frozen at $-70{ }^{\circ} \mathrm{C}$ for microbial enzymes activity determination. The microbial enzymes ( $\beta$-glucosidase and $\beta$-glucuronidase) activity was measured by the rate of $p$ - or o-nitrophenol release from their nitrophenyl-glucosides and expressed as $\mu \mathrm{mol}$ of product formed per minute $(1 \mu \mathrm{mol} / \mathrm{min}=1$ Unit $)$ per gram of caecal digesta [28].

After 4 weeks, the rats were anaesthetized using sodium pentobarbitone. Blood samples were taken from aorta. Serum was prepared by centrifugation at $1,500 \mathrm{~g}$ for $15 \mathrm{~min}$ at $4{ }^{\circ} \mathrm{C}$ and stored at $-40{ }^{\circ} \mathrm{C}$ until analysed. After laparotomy, the selected parts of the digestive tract (small intestine, caecum and colon) were removed and weighed. As soon as possible after euthanasia (ca. $10 \mathrm{~min}$ ), ileal, caecal and colonic $\mathrm{pH}$ were measured, sample of digesta was taken to determine dry matter, ammonia and SCFA and the rest were frozen at $-70{ }^{\circ} \mathrm{C}$ for microbial enzymes activity determination. The ileal, caecal and colonic walls were flushed clean with ice-cold saline, blotted on filter paper and weighed as the tissue weight.

The caecal $\mathrm{pH}$ was measured using a microelectrode and a pH/ION metre (model 301, Hanna Instruments, Vila do Conde, Portugal). Dry matter of fresh digesta was measured at $105{ }^{\circ} \mathrm{C}$. Ammonia was extracted and trapped in a solution of boric acid, then determined by direct titration with sulphuric acid [29]. The amounts of SCFA were measured using gas chromatography under conditions described previously [28]. The SCFA pool size in a caecum was calculated as the product of SCFA concentration and caecal digesta mass. The microbial enzymes $(\alpha-$ and $\beta$-glucosidase, $\alpha$ - and $\beta$-galactosidase and $\beta$-glucuronidase) activity was measured by the rate of p- or o-nitrophenol release from their nitrophenyl-glucosides and expressed as $\mu \mathrm{mol}$ of product formed per minute $(1 \mu \mathrm{mol} / \mathrm{min}=1 \mathrm{Unit})$ per gram of caecal digesta [28].

All results obtained were worked out statistically using a two-way analysis of variance and the Duncan's multiple range test at a significance level of $P \leq 0.05$ using STATISTICA 6.0 (StatSoft Corp., Kraków, Poland) software.

\section{Results}

Composition of polyphenolic preparations

The PTW preparation was characterized by a significant content of dietary fibre in the form of soluble fibre $(21.95 \%)$ and a relatively small content of polyphenols (5.6\%) (Table 2). In the PTE preparation, the content of soluble fibre was lower $(10.2 \%)$, whereas the content of polyphenols considerably higher $(28.8 \%)$. Over $50 \%$ of the dry matter of both preparations were carbohydrates (in the PTE extract without low-molecular carbohydrates) as well as crude ash and crude protein, particularly in the PTE preparation. The main group of polyphenols in the analysed strawberry extracts was represented by ellagic acid which, along with the ellagic acid bound with ellagitannins, constituted $90.4 \%$ of total polyphenols of the PTW extract and $59.3 \%$ of total polyphenols of the PTE preparation. In the PTW preparation, flavonols (mainly quercetin and kaempferol glycosides) and proanthocyanidins constituted additionally 4 and $3.6 \%$ of total polyphenols, respectively. In the PTE preparation, second in terms of quantity was the group of proanthocyanidins (38\%), whereas flavonol aglycones (quercetin and kaempferol) and p-coumaric acid constituted the small remaining part.

In both preparations, the most important group of strawberry polyphenols was ellagitannins; however, in the

Table 2 Chemical composition of polyphenolic preparations

\begin{tabular}{|c|c|c|}
\hline & \multicolumn{2}{|c|}{ Phenolic preparations } \\
\hline & PTW & PTE \\
\hline \multicolumn{3}{|l|}{ Basic composition, $\mathrm{g} / 100 \mathrm{~g}$} \\
\hline Dry matter & 97.21 & 97.00 \\
\hline Crude ash & 7.59 & 1.78 \\
\hline Crude protein & 7.86 & 4.58 \\
\hline Ether extract & 0.00 & 0.00 \\
\hline Dietary fibre (DF) & 21.95 & 10.24 \\
\hline Low-molecular carbohydrates ${ }^{\mathrm{a}}$ & 22.98 & nd \\
\hline Other carbohydrates & 31.19 & 51.58 \\
\hline Polyphenolic compounds & 5.64 & 28.82 \\
\hline \multicolumn{3}{|l|}{ Polyphenolic composition, g/100 g } \\
\hline Free ellagic acid & $0.40(7.09)$ & $1.20(4.16)$ \\
\hline Bound ellagic acid & $4.70(83.33)$ & $15.90(55.17)$ \\
\hline Total ellagic acid & $5.10(90.43)$ & $17.10(59.33)$ \\
\hline P-coumaric acid & $0.01(0.18)$ & $0.02(0.07)$ \\
\hline P-coumaric acid derivative & $0.00(0.00)$ & $0.07(0.24)$ \\
\hline Quercetin glucoside & $0.01(0.18)$ & $0.03(0.10)$ \\
\hline Quercetin glucuronide & $0.15(2.66)$ & $0.29(1.01)$ \\
\hline Kaempferol glucoside & $0.05(0.89)$ & $0.11(0.38)$ \\
\hline Quercetin & $0.01(0.18)$ & $0.20(0.69)$ \\
\hline Kaempferol & $0.00(0.00)$ & $0.10(0.35)$ \\
\hline Anthocyanins & $0.01(0.18)$ & $0.00(0.00)$ \\
\hline Proanthocyanidins (PC) & $0.20(3.55)$ & $10.90(37.80)$ \\
\hline
\end{tabular}

Values in brackets present per cent of individual component or a group to the total polyphenols

PTW strawberry polyphenols water extract, PTE strawberry polyphenols ethanol extract

a Saccharose, glucose and fructose, $10.33 ; 10.87$ and 1.78 , respectively, PTE strawberry polyphenols ethanol extract, $P T W$ strawberry polyphenols water extract 
water extract (PTW), the content of other polyphenols was at a minimal level, whereas in the water-methanol extract of a considerable contribution was polymerized proanthocyanidins. As it results from the calculation of the components of both pomace and the resultant PTW preparation, the yield of water extraction of polyphenols from pomace amounted to $36.7 \%$, including $24.5 \%$ of ellagitannins. The application of the water-methanol extraction of pomace increased extraction performance of the total polyphenols to $59.5 \%$, including that of ellagitannins to $35.3 \%$ and that of proanthocyanidins to $14 \%$.

Animal growth and indices of gastrointestinal functioning

The applied dietary treatments had no effect on diet intake nor body weight gain of rats, but still they influenced some parameters of the gastrointestinal tract (Table 3). The addition of polyphenolic extracts to a diet increased the amount of caecal digesta, yet only in the case of the PTW extract was this amount statistically higher than in the control group $(P=0.001)$. In comparison with the rats receiving cellulose in their diets, the diets with FOS significantly increased the mass of the small intestine with digesta as well as the mass of caecal digesta (both $P=0.001)$. The addition of FOS to a diet resulted also in the reduction in digesta $\mathrm{pH}$ in the small intestine and in the caecum and in the reduction in dry matter content of caecal digesta $(P=0.001)$. A significant correlation $(P=0.007)$ was noted between the type of extract from strawberry pomace (PTW or PTE) and the type of dietary fibre (cellulose or FOS) only in the case of the mass of the small intestine with digesta. It was due to the fact that the addition of PTE preparation reduced the effect of FOS on the mass of the small intestine with digesta recorded in control groups and groups fed a diet with the PTW preparation.

\section{Glycolytic activity of microflora and the concentration of short-chain fatty acids}

The administration of the compared sources of strawberry polyphenols in a diet in the dose of $0.6 \mathrm{~g}$ of ellagic acid $/ \mathrm{kg}$ diversified the activity of bacterial $\beta$-glucosidase and $\beta$-glucuronidase in faeces of the rats (Table 4 , Figs. 1 and 2). In the rats receiving diets containing both polyphenolic

Table 3 Diet intake (DI), body weight gain (BWG) and parameters of rat intestines development and functioning

\begin{tabular}{|c|c|c|c|c|c|c|c|c|}
\hline & \multirow[t]{2}{*}{ DI $g / 28 \mathrm{~d}$} & \multirow[t]{2}{*}{ BWG $g / 28 d$} & \multicolumn{2}{|l|}{ Small intesine } & \multicolumn{4}{|l|}{ Caecum } \\
\hline & & & $\begin{array}{l}\text { Weight, } g / 100 \mathrm{~g} \\
\text { of BW }\end{array}$ & $\mathrm{pH}$ & $\begin{array}{l}\text { Content } g / 100 \mathrm{~g} \\
\text { of BW }\end{array}$ & Dry matter, \% & $\begin{array}{l}\text { Ammonia mg/100 g } \\
\text { of digesta }\end{array}$ & $\mathrm{pH}$ \\
\hline \multicolumn{9}{|l|}{ Treatment } \\
\hline $\mathrm{C}_{\mathrm{C}}$ & 489.8 & 120.4 & $3.07^{\mathrm{c}}$ & 7.01 & 0.85 & 24.4 & 0.25 & 7.05 \\
\hline $\mathrm{C}_{\mathrm{FOS}}$ & 491.7 & 122.7 & $3.45^{\mathrm{ab}}$ & 6.68 & 1.34 & 18.1 & 0.23 & 6.64 \\
\hline $\mathrm{PTW}_{\mathrm{C}}$ & 534.6 & 131.3 & $2.95^{\mathrm{c}}$ & 7.03 & 1.24 & 22.7 & 0.26 & 7.03 \\
\hline PTW $_{\text {FOS }}$ & 512.9 & 132.5 & $3.64^{\mathrm{a}}$ & 6.79 & 1.66 & 16.5 & 0.26 & 6.82 \\
\hline $\mathrm{PTE}_{\mathrm{C}}$ & 522.9 & 127.3 & $3.13^{c}$ & 6.98 & 1.14 & 22.5 & 0.24 & 7.02 \\
\hline $\mathrm{PTE}_{\mathrm{FOS}}$ & 515.3 & 124.3 & $3.22^{\mathrm{bc}}$ & 6.80 & 1.41 & 18.0 & 0.26 & 6.80 \\
\hline SEM & 7.11 & 2.18 & 0.05 & 0.03 & 0.05 & 0.58 & 0.01 & 0.04 \\
\hline \multicolumn{9}{|l|}{ Phenolic (P) } \\
\hline $\mathrm{C}$ & 490.7 & 121.5 & 3.27 & 6.84 & $1.09^{\mathrm{b}}$ & 21.3 & 0.24 & 6.84 \\
\hline PTW & 523.8 & 131.9 & 3.30 & 6.91 & $1.45^{\mathrm{a}}$ & 19.6 & 0.26 & 6.92 \\
\hline PTE & 519.1 & 125.8 & 3.18 & 6.89 & $1.27^{\mathrm{ab}}$ & 20.3 & 0.26 & 6.91 \\
\hline$P$ value & 0.134 & 0.169 & 0.380 & 0.624 & 0.001 & 0.264 & 0.432 & 0.599 \\
\hline \multicolumn{9}{|l|}{ Fibre $(\mathrm{F})$} \\
\hline Cellulose & 515.8 & 126.3 & $3.05^{\mathrm{b}}$ & $7.00^{\mathrm{a}}$ & $1.07^{\mathrm{b}}$ & $23.2^{\mathrm{a}}$ & 0.25 & $7.03^{\mathrm{a}}$ \\
\hline FOS & 506.6 & 126.5 & $3.44^{\mathrm{a}}$ & $6.76^{\mathrm{b}}$ & $1.47^{\mathrm{a}}$ & $17.5^{\mathrm{b}}$ & 0.25 & $6.76^{\mathrm{b}}$ \\
\hline$P$ value & 0.523 & 0.969 & 0.001 & 0.001 & 0.001 & 0.001 & 0.752 & 0.000 \\
\hline Interaction $\mathrm{P} \times \mathrm{F}$ & 0.792 & 0.876 & 0.007 & 0.578 & 0.484 & 0.623 & 0.536 & 0.422 \\
\hline
\end{tabular}

$D I$ diet intake, $B W G$ body weight gain, $B W$ body weight, $C_{C}$ control diet with cellulose, $C_{F O S}$ control diet with fructooligosaccharides, $P T E_{C}$ diet with strawberry polyphenols ethanol extract with cellulose, $P T E_{F O S}$ diet with strawberry polyphenols ethanol extract with fructooligosaccharides, $P T W_{C}$ diet with strawberry polyphenols water extract with cellulose, $P T W_{F O S}$ diet with strawberry polyphenols water extract with fructooligosaccharides, $P T W$ strawberry polyphenols water extract, $P T E$ strawberry polyphenols ethanol extract, $C$ cellulose, FOS fructooligosaccharides Values in columns marked with different letters are statistically different at $\mathrm{p}<0.05$ 
extracts, the activity of $\beta$-glucosidase in faeces was significantly lower in all the analysed periods. The content of FOS in a diet suppressed the activity of $\beta$-glucosidase, however, only on the 28th day of the experiment was the difference statistically significant compared to the diet with cellulose $(P=0.001)$. A statistically significant effect of FOS on the activity of $\beta$-glucosidase was recorded only in the case of diets with PTE preparation. The applied dietary treatments had a diversified effect on the activity of $\beta$-glucosidase in rat faeces. Significant reductions in its activity were recorded in rats receiving diets with the PTW preparation. A similar effect of the PTE preparation was statistically significant only on days 7 and 21 of the experiment. A statistically significant correlation regarding the effect of both experimental factors (extracts from strawberry pomace and type of dietary fibre in a diet) on the activity of $\beta$-glucosidase was recorded in faeces of 28-week-old rats. This resulted from the fact that the PTE addition to a diet with FOS significantly reduced the activity of this enzyme in relation to the diet with cellulose, whilst PTW addition did not evoke such an effect. In the case of $\beta$-glucuronidase, an inverse tendency was reported. The concurrent application of PTW and FOS yielded a significant decrease in the activity of this enzyme, whereas PTE addition did not trigger such an effect.

The applied dietary treatments decreased the activity of caecal microflora enzymes of rats (Table 5). The results of a two-way anova indicate that both extracts from strawberry pomace reduced the activity of $\alpha$-galactosidase and $\beta$-glucuronidase $(P=0.001)$. The activity of both of these enzymes and of $\beta$-glucosidase was lower in the ceacal digesta of rats receiving diets with FOS. Only in the case of $\beta$-glucuronidase, a close to statistical significance interaction was recorded in the effect of strawberry pomace extracts and dietary fibre $(P=0.081)$, which resulted from the fact that the PTW preparation intensified the inhibition of this enzyme activity by FOS to a greater extent than the PTE preparation did.

The applied dietary treatments diversified also the concentration of short-chain fatty acids (SCFA) in caecal digesta of rats (Table 6). The results of the two-way anova indicate that in comparison with $\mathrm{C}$ diets, the diets with PTW and PTE significantly decreased the concentration of acetic acid, propionic and butyric acids. In rats receiving PTW and PTE in a diet, the concentration of the total SCFAs was significantly lower than in groups C (58.6 and

Table 4 Activity of $\beta$-glucosidase and $\beta$-glucuronidase ( $\mu \mathrm{mol} / \mathrm{h} / \mathrm{g}$ faeces) in rat faeces in the successive days of the experiment $(0,7,14,21$ and 28)

\begin{tabular}{|c|c|c|c|c|c|c|c|c|c|c|}
\hline & \multicolumn{5}{|c|}{$\beta$-glucosidase (day) } & \multicolumn{5}{|c|}{$\beta$-glucuronidase (day) } \\
\hline & 0 & 7 & 14 & 21 & 28 & 0 & 7 & 14 & 21 & 28 \\
\hline \multicolumn{11}{|l|}{ Treatment } \\
\hline $\mathrm{C}_{\mathrm{C}}$ & 16.7 & 11.7 & 14.2 & 16.4 & $7.31^{\mathrm{b}}$ & 52.2 & 48.9 & 57.4 & 53.9 & 45.0 \\
\hline $\mathrm{C}_{\mathrm{FOS}}$ & & 13.3 & 15.9 & 16.1 & $6.41^{\mathrm{bc}}$ & & 34.3 & 35.4 & 35.0 & 24.3 \\
\hline $\mathrm{PTW}_{\mathrm{C}}$ & & 9.89 & 10.3 & 9.53 & $4.53^{\mathrm{cd}}$ & & 25.5 & 25.4 & 21.8 & 18.5 \\
\hline $\mathrm{PTW}_{\mathrm{FOS}}$ & & 5.24 & 5.26 & 7.12 & $3.33^{\mathrm{d}}$ & & 13.3 & 12.6 & 16.4 & 10.4 \\
\hline $\mathrm{PTE}_{\mathrm{C}}$ & & 10.3 & 12.6 & 10.7 & $10.3^{\mathrm{a}}$ & & 31.3 & 38.1 & 24.9 & 41.2 \\
\hline $\mathrm{PTE}_{\mathrm{FOS}}$ & & 7.95 & 7.89 & 7.81 & $3.43^{\mathrm{d}}$ & & 31.9 & 36.4 & 21.8 & 22.4 \\
\hline SEM & & 0.73 & 0.89 & 0.94 & 0.43 & & 2.16 & 2.64 & 2.31 & 2.19 \\
\hline \multicolumn{11}{|l|}{ Phenolic (P) } \\
\hline $\mathrm{C}$ & & $12.5^{\mathrm{a}}$ & $15.1^{\mathrm{a}}$ & $16.2^{\mathrm{a}}$ & $6.86^{\mathrm{a}}$ & & $41.6^{\mathrm{a}}$ & $46.4^{\mathrm{a}}$ & $44.5^{\mathrm{a}}$ & $34.7^{\mathrm{a}}$ \\
\hline PTW & & $7.56^{\mathrm{b}}$ & $7.77^{\mathrm{b}}$ & $8.33^{\mathrm{b}}$ & $3.93^{\mathrm{b}}$ & & $19.4^{\mathrm{c}}$ & $19.0^{\mathrm{b}}$ & $19.1^{\mathrm{b}}$ & $14.4^{\mathrm{b}}$ \\
\hline PTE & & $9.10^{\mathrm{b}}$ & $10.2^{\mathrm{b}}$ & $9.26^{\mathrm{b}}$ & $6.85^{\mathrm{a}}$ & & $31.6^{\mathrm{b}}$ & $37.2^{\mathrm{a}}$ & $23.4^{\mathrm{b}}$ & $31.8^{\mathrm{a}}$ \\
\hline$P$ value & & 0.013 & 0.001 & 0.001 & 0.001 & & 0.001 & 0.001 & 0.001 & 0.001 \\
\hline \multicolumn{11}{|l|}{ Fibre $(\mathrm{F})$} \\
\hline Cellulose & & 10.6 & 12.4 & 12.2 & $7.37^{\mathrm{a}}$ & & $35.2^{\mathrm{a}}$ & $40.3^{\mathrm{a}}$ & $33.5^{\mathrm{a}}$ & $34.9^{\mathrm{a}}$ \\
\hline FOS & & 8.83 & 9.68 & 10.3 & $4.39^{\mathrm{b}}$ & & $26.5^{\mathrm{b}}$ & $28.2^{\mathrm{b}}$ & $24.4^{\mathrm{b}}$ & $19.0^{\mathrm{b}}$ \\
\hline$P$ value & & 0.194 & 0.080 & 0.256 & 0.001 & & 0.009 & 0.002 & 0.004 & 0.001 \\
\hline Interaction $\mathrm{P} \times \mathrm{F}$ & & 0.163 & 0.135 & 0.787 & 0.001 & & 0.128 & 0.096 & 0.078 & 0.132 \\
\hline
\end{tabular}

$C_{C}$ control diet with cellulose, $C_{F O S}$ control diet with fructooligosaccharides, $P T E_{C}$ diet with strawberry polyphenols ethanol extract with cellulose, $P T E_{F O S}$ diet with strawberry polyphenols ethanol extract with fructooligosaccharides, $P T W_{C}$ diet with strawberry polyphenols water extract with cellulose, $P T W_{F O S}$ diet with strawberry polyphenols water extract with fructooligosaccharides, $P T W$ strawberry polyphenols water extract, $P T E$ strawberry polyphenols ethanol extract, $C$ cellulose, FOS fructooligosaccharides

Values in columns marked with different letters are statistically different at $\mathrm{p}<0.05$ 


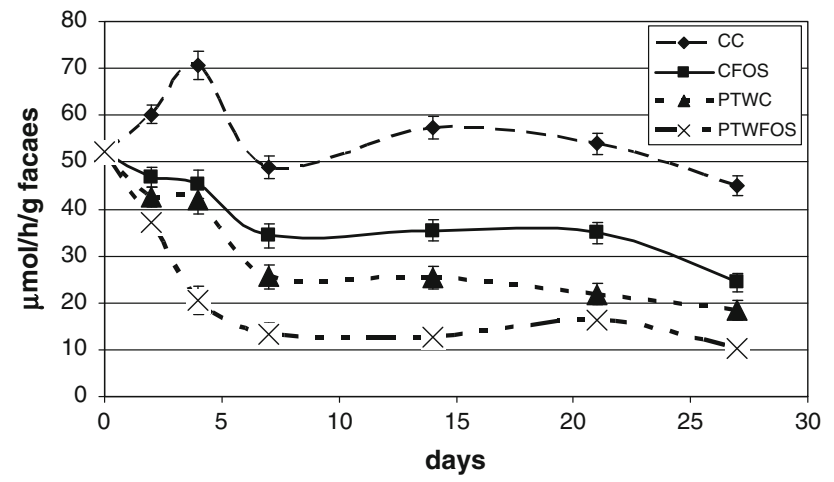

Fig. 1 Activity of faecal $\beta$-glucuronidase of PTW preparation compared to control groups. $C_{C}$ control diet with cellulose, $C_{F O S}$ control diet with fructooligosaccharides, $P T W_{C}$ diet with strawberry polyphenols water extract with cellulose, $P T W_{F O S}$ diet with strawberry polyphenols water extract with fructooligosaccharides

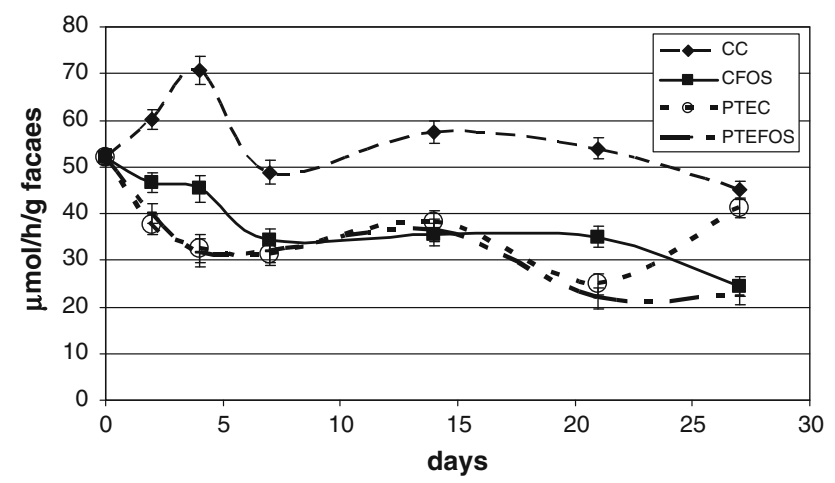

Fig. 2 Activity of faecal $\beta$-glucuronidase of PTE preparation compared to control groups. $C_{C}$ control diet with cellulose, $C_{F O S}$ control diet with fructooligosaccharides, $P T E_{C}$ diet with strawberry polyphenols ethanol extract with cellulose, $P T E_{F O S}$ diet with strawberry polyphenols ethanol extract with fructooligosaccharides

56.4 vs. $75.6 \mu \mathrm{mol} / \mathrm{g}, P=0.001)$. Taking into consideration the differences in the amount of caecal digesta of rats, the total SCFAs content in the digesta was similar in rats from the control group and in those receiving the diet with PTW, whereas significantly lower in rats receiving the diet with PTE ( 83.7 and 86.1 vs. $71.4 \mu \mathrm{mol} / 100 \mathrm{~g} \mathrm{BW}, P=0.002$ ). Due to the differences in the amount of caecal digesta, the pool of $\mathrm{C} 4$ and C5 fatty acids was similar and slightly changed due to the administration of the compared preparations.

In relation to the diets with cellulose, the content of FOS increased the pool of SCFAs in caecal digesta of rats, which may be attributed to increased concentrations of acetic acid, propionic and butyric acids and a slightly reduced concentration of isobutyric acid induced by FOS. A statistically significant correlation was recorded regarding the effect of both experimental factors on the concentration of selected fatty acids, including propionic $(P=0.002)$, isobutyric $(P=0.001)$, isovaleric $(P=0.047)$ acids, the total SCFAs $(P=0.005)$ and the pool of SCFA $(P=0.002)$. In the
Table 5 Activity of microbial enzymes in caecal digesta of rats $\mu \mathrm{mol} / \mathrm{h} / \mathrm{g}$

\begin{tabular}{clll}
$\frac{\text { Glucosidase }}{\alpha} \beta$ & $\frac{\text { Galactosidase }}{\alpha} \beta$-glucuronidase \\
\hline
\end{tabular}

\begin{tabular}{lccccc}
\hline Treatment & & & & & \\
$\mathrm{C}_{\mathrm{C}}$ & 7.17 & 2.41 & 5.84 & 4.58 & 18.8 \\
$\mathrm{C}_{\mathrm{FOS}}$ & 5.93 & 1.54 & 4.72 & 5.44 & 9.28 \\
PTW $_{\mathrm{C}}$ & 6.21 & 1.80 & 3.88 & 4.93 & 9.22 \\
PTW $_{\text {FOS }}$ & 5.46 & 1.43 & 3.02 & 5.43 & 5.96 \\
PTE $_{\mathrm{C}}$ & 7.47 & 1.75 & 3.74 & 4.23 & 10.5 \\
PTE $_{\mathrm{FOS}}$ & 6.88 & 1.22 & 2.52 & 4.52 & 7.86 \\
SEM & 0.32 & 0.10 & 0.27 & 0.30 & 0.87 \\
Phenolic (P) & & & & & \\
C & 6.55 & 1.97 & $5.28^{\mathrm{a}}$ & 5.01 & $14.0^{\mathrm{a}}$ \\
PTW & 5.84 & 1.61 & $3.45^{\mathrm{b}}$ & 5.18 & $7.59^{\mathrm{b}}$ \\
PTE & 7.18 & 1.49 & $3.13^{\mathrm{b}}$ & 4.37 & $9.20^{\mathrm{b}}$ \\
$P$ value & 0.239 & 0.087 & 0.001 & 0.547 & 0.001 \\
Fibre $(\mathrm{F})$ & & & & & \\
Cellulose & 6.95 & $1.99^{\mathrm{a}}$ & $4.48^{\mathrm{a}}$ & 4.58 & $12.9^{\mathrm{a}}$ \\
FOS & 6.09 & $1.40^{\mathrm{b}}$ & $3.42^{\mathrm{b}}$ & 5.13 & $7.70^{\mathrm{b}}$ \\
$P$ value & 0.181 & 0.002 & 0.026 & 0.385 & 0.001 \\
Interaction P $\times \mathrm{F}$ & 0.909 & 0.524 & 0.947 & 0.932 & 0.081
\end{tabular}

$C_{C}$ control diet with cellulose, $C_{F O S}$ control diet with fructooligosaccharides, $P T E_{C}$ diet with strawberry polyphenols ethanol extract with cellulose, $P T E_{F O S}$ diet with strawberry polyphenols ethanol extract with fructooligosaccharides, $P T W_{C}$ diet with strawberry polyphenols water extract with cellulose, $P T W_{F O S}$ diet with strawberry polyphenols water extract with fructooligosaccharides, $P T W$ strawberry polyphenols water extract, $P T E$ strawberry polyphenols ethanol extract, $C$ cellulose, FOS fructooligosaccharides

Values in columns marked with different letters are statistically different at $\mathrm{p}<0.05$

majority of cases, this was due to the synergic effect of FOS and PTW preparation. In contrast, the PTE preparation was found not to affect the physiological effects of FOS. Relatively significant differences in the concentration of butyric acid in groups C, PTW and PTE were considerably smaller (11.3, 9.22 and $12.2 \mu \mathrm{mol} / 100 \mathrm{~g} \mathrm{BW}$, respectively) when pools of these acids were compared (data not presented). Likewise, some differences were noted in the concentration of other $\mathrm{C} 4$ and $\mathrm{C} 5$ fatty acids in the caecal digesta; however, the pool of the total sum of these acids was similar. The pool of $\mathrm{C} 4 \mathrm{i}, \mathrm{C} 5 \mathrm{i}$ and $\mathrm{C} 5$ acids, defined as putrefactive SCFAs, amounted to 2.62, 3.56 and 2.59 $\mu \mathrm{mol} / 100 \mathrm{~g} \mathrm{BW}$, respectively, for C, PTW and PTE groups.

\section{Discussion}

The results of the presented study indicate that water extract polyphenols consisted in $90 \%$ of ellagitannins, 
with a small contribution of flavonols, including proanthocyanidins. In comparison with the water extract, the ethanol extract contained over 5 times more polyphenols, whilst nearly $60 \%$ of these were constituted by ellagitannins and almost the whole rest $(38 \%$ of the total of polyphenols) by polymerised proanthocyanidins. The determined differences resulted from both various effectiveness of extraction with water and alcohol and from polyphenols content in pomace, a material differing from the well-characterized strawberry fruit.

As it results from studies of many authors, contents of key polyphenols present in fresh strawberry fruits fits within a wide range, i.e. for free and bound ellagic acidbetween 130 and $850 \mathrm{mg} / \mathrm{kg}$ of fresh fruits [30-32], respectively, for proanthocyanidins-from below 10 to more than $160 \mathrm{mg} / \mathrm{kg}$ [33, 34], for anthocyanins-from 124 to $600 \mathrm{mg} / \mathrm{kg}[30,35]$, for coumaric acid-from 9 to $102 \mathrm{mg} / \mathrm{kg}[30,36]$ and for flavonols_-from 5 to $65 \mathrm{mg} / \mathrm{kg}$ [30-32]. The results obtained were found to depend on the variety and the origin of strawberry fruits as well as on the analytical methods applied [37]. For instance, with the thiol method applied, the determined content of proanthocyanidins accounted for up to $2.75 \mathrm{~g} / \mathrm{kg}$ [38].

As it results from sparse analyses of the content and composition of strawberry pomace polyphenols, about half of the content of ellagitannins in processed strawberry fruits is to be found in juice and the rest remains in pomace, out of which $35 \%$ in the pulp and ca. $15 \%$ in the seeds [6, 30]. The content of ellagitannins in pomace amounts to 1,020-1,420 mg/100 g dm [6], whilst other pomace components include ellagic, p-coumaric, p-benzoic acids, quercetin, kaempferol and anthocyanins with contents of $95,14,4,50,60$ and $30 \mathrm{mg} / 100 \mathrm{~g} \mathrm{dm}$, respectively [22]. The content of proanthocyanidins in strawberry pomace may reach even $2.5 \%$ as they are bound with insoluble polysaccharides of the cell wall, which results in only a small part of these compounds being found in juices [38]. Also for this reason, the water extract obtained in the study contained a small amount of proanthocyanidins, whose content in the extract was increased by the use of alcohol. Moreover, proanthocyanidins are found in higher quantity in strawberry achenes [30], and the pomace used in the experiment was seedless. In proanthocyanidins of strawberries, (epi)catechin is the main building block, but propelargonidin [(epi)afzelechin] is also present (6-10\% of the proanthocyanidins) [34]. Because we used only $(+)$-catechin and (-)-epicatechin as standards for phloroglucinolysis we might have underestimated the content of proanthocyanidins.

In the presented experiment, the applied doses of polyphenolic extracts in a diet contribute an equivalent amount of $0.06 \%$ of ellagic acid and a relatively small content of other components, crude protein and carbohydrates, including dietary fibre. Such an addition of polyphenols did not reduce diet intake nor body weight of experimental rats, but had an effect on the activity of some of the enzymes of intestinal microflora and its most important products. It is common knowledge that the physiological effect of polyphenols is determined by both the content of these compounds in a diet as well as their physiochemical properties, including the level of polymerization [15, 21]. As it results from the experiments of other authors, polymeric proanthocyanidins travel through the acidic environment of the stomach unchanged [39] and their considerable amount remains in the digesta of the lower section of the gastrointestinal tract [40]. Even with a high consumption of proanthocyanidins, relatively low, nanomolar concentration of their derivatives, proanthocyanidin dimers, was recorded in volunteers' blood [41]. The increased excretion of phenolic acids with urine of volunteers consuming diets rich in proanthocyanidins indicates that these compounds are partially degraded by the microflora colonizing the gastrointestinal tract [42]. Worthy of notice is, however, that an increased content of these compounds might reduce the activity of digestive enzymes [41].

Polyphenolic extracts applied in the presented experiment reduced the activity of some enzymes of the intestinal microflora, above all of $\beta$-glucosidase and $\beta$-glucuronidase in caecal digesta and faeces. The microbial $\beta$-glucuronidase is acknowledged as a good marker of microflora deconjugating activity [43], whereas its reduced activity-as a beneficial phenomenon minimizing the risk of xenobiotics transformation into toxic substances which take part in the process of cancer induction [44]. The increase in the hydrolytic activity of $\beta$-glucosidase has both a negative and a positive meaning, as $\beta$-glucosidase participates in the synthesis of both toxins and anti-carcinogens [45].

Results obtained in the presented experiment indicate that the content of polyphenolic extracts from strawberry pomace in diets significantly reduced the activity of $\alpha$-galactosidase and $\beta$-glucuronidase, which resulted in a reduced concentration of SCFAs in caecal digesta of rats. Results of other authors indicate that the increased content of polyphenols in a diet may inhibit the growth and reduce the abundance of gastrointestinal microflora [46, 47]. It was denoted that the flavonoid extract applied as a dietary supplement was to decrease the activity of bacterial $\beta$-glucosidase and $\beta$ - and $\alpha$-galactosidases in the caecal digesta of rats [47].

It was noted in the presented experiment that the wateralcohol extract, unlike the water extract, reduced the total production of SCFAs in caecal digesta. Such an effect should be explained by a higher content of dietary fibre and other carbohydrates in the water extract. In the experiment by Aprikian et al. [48], an apple pectin and a 
Table 6 Concentration of short-chain fatty acids (SCFA) in ceacal digesta

\begin{tabular}{|c|c|c|c|c|c|c|c|c|}
\hline & \multicolumn{7}{|c|}{ SCFA concentration, $\mu \mathrm{mol} / \mathrm{g}$} & \multirow[t]{2}{*}{ SCFA pool $\mu \mathrm{mol} / 100 \mathrm{~g} \mathrm{BW}$} \\
\hline & $\mathrm{C} 2$ & $\mathrm{C} 3$ & $\mathrm{C} 4 \mathrm{i}$ & $\mathrm{C} 4$ & C5i & C5 & Total & \\
\hline \multicolumn{9}{|l|}{ Treatment } \\
\hline $\mathrm{C}_{\mathrm{C}}$ & 40.5 & $15.3^{\mathrm{b}}$ & $1.20^{\mathrm{a}}$ & 8.55 & $1.03^{\mathrm{a}}$ & 0.93 & $67.5^{\mathrm{b}}$ & $56.9^{\mathrm{c}}$ \\
\hline $\mathrm{C}_{\mathrm{FOS}}$ & 46.7 & $23.2^{\mathrm{a}}$ & $0.28^{\mathrm{d}}$ & 12.24 & $0.61^{\mathrm{b}}$ & 0.75 & $83.7^{\mathrm{a}}$ & $110.5^{\mathrm{a}}$ \\
\hline $\mathrm{PTW}_{\mathrm{C}}$ & 34.8 & $9.95^{\mathrm{c}}$ & $0.56^{\mathrm{bc}}$ & 5.44 & $0.74^{\mathrm{ab}}$ & 0.92 & $52.4^{\mathrm{c}}$ & $64.7^{\mathrm{c}}$ \\
\hline PTW $_{\text {FOS }}$ & 41.6 & $13.2^{\mathrm{b}}$ & $0.76^{\mathrm{b}}$ & 7.29 & $0.88^{\mathrm{ab}}$ & 1.06 & $64.7^{\mathrm{b}}$ & $107.4^{\mathrm{a}}$ \\
\hline $\mathrm{PTE}_{\mathrm{C}}$ & 31.1 & $13.6^{\mathrm{b}}$ & $0.51^{\mathrm{c}}$ & 7.39 & $0.90^{\mathrm{ab}}$ & 0.73 & $58.7^{\mathrm{bc}}$ & $67.0^{\mathrm{c}}$ \\
\hline $\mathrm{PTE}_{\mathrm{FOS}}$ & 31.1 & $13.7^{\mathrm{b}}$ & $0.51^{\mathrm{c}}$ & 11.8 & $0.70^{\mathrm{ab}}$ & 0.69 & $54.1^{\mathrm{c}}$ & $75.7^{\mathrm{bc}}$ \\
\hline SEM & 1.14 & 0.72 & 0.05 & 0.55 & 0.04 & 0.03 & 1.96 & 3.10 \\
\hline \multicolumn{9}{|l|}{ Phenolic (P) } \\
\hline $\mathrm{C}$ & $43.6^{\mathrm{a}}$ & $19.2^{\mathrm{a}}$ & $0.74^{\mathrm{a}}$ & $10.4^{\mathrm{a}}$ & 0.82 & $0.84^{\mathrm{ab}}$ & $75.6^{\mathrm{a}}$ & $83.7^{\mathrm{ab}}$ \\
\hline PTW & $38.2^{\mathrm{b}}$ & $11.6^{\mathrm{b}}$ & $0.66^{\mathrm{ab}}$ & $6.36^{\mathrm{b}}$ & 0.81 & $0.99^{\mathrm{a}}$ & $58.6^{\mathrm{b}}$ & $86.1^{\mathrm{a}}$ \\
\hline PTE & $31.1^{\mathrm{c}}$ & $13.7^{\mathrm{b}}$ & $0.51^{\mathrm{b}}$ & $9.61^{\mathrm{a}}$ & 0.80 & $0.71^{\mathrm{b}}$ & $56.4^{\mathrm{b}}$ & $71.4^{\mathrm{b}}$ \\
\hline$P$ value & 0.001 & 0.001 & 0.009 & 0.001 & 0.985 & 0.001 & 0.001 & 0.002 \\
\hline \multicolumn{9}{|l|}{ Fibre $(F)$} \\
\hline Cellulose & $34.5^{\mathrm{b}}$ & $13.0^{\mathrm{b}}$ & $0.76^{\mathrm{a}}$ & $7.39^{\mathrm{b}}$ & 0.89 & 0.86 & $59.5^{\mathrm{b}}$ & $63.6^{\mathrm{b}}$ \\
\hline FOS & $39.8^{\mathrm{a}}$ & $16.7^{\mathrm{a}}$ & $0.51^{\mathrm{b}}$ & $10.5^{\mathrm{a}}$ & 0.73 & 0.83 & $67.5^{\mathrm{a}}$ & $95.1^{\mathrm{a}}$ \\
\hline$P$ value & 0.011 & 0.001 & 0.001 & 0.001 & 0.080 & 0.620 & 0.004 & 0.001 \\
\hline Interaction $\mathrm{P} \times \mathrm{F}$ & 0.182 & 0.002 & 0.001 & 0.471 & 0.047 & 0.085 & 0.005 & 0.002 \\
\hline
\end{tabular}

$C_{C}$ control diet with cellulose, $C_{F O S}$ control diet with fructooligosaccharides, $P T E_{C}$ diet with strawberry polyphenols ethanol extract with cellulose, $P T E_{F O S}$ diet with strawberry polyphenols ethanol extract with fructooligosaccharides, $P T W_{C}$ diet with strawberry polyphenols water extract with cellulose, $P T W_{F O S}$ diet with strawberry polyphenols water extract with fructooligosaccharides, $P T W$ strawberry polyphenols water extract, PTE strawberry polyphenols ethanol extract, $C$ cellulose, FOS fructooligosaccharides

Values in columns marked with different letters are statistically different at $\mathrm{p}<0.05$

polyphenol-rich apple concentrate were more effective together than separately on caecal fermentation in rats. Similarly, in the experiment by Zdunczyk et al. [47], dietary addition of inulin to the flavonoid-diet increased activity of glycolytic enzymes of intestinal microflora, normalized hydration of digesta and significantly decreased the $\mathrm{pH}$ of caecal digesta.

The reported study showed also that the presence of FOS in a diet reduced the activity of microbial $\beta$-glucuronidase and simultaneously increased the production of SCFAs, including acetic acid, propionic and butyric acids in caecal digesta. This was consistent with findings of other authors from studies with fructooligosaccharides, oligosaccharides of other types or inulin [47, 49, 50]. As it results from a research by McBain and Macfarlane [51], the highest activity of $\beta$-glucuronidase is typical of Escherichia coli and Clostridium. Reduction in $\beta$-glucuronidase activity, without compromising other glycolytic enzymes, may be an indicator of favourable changes in the gut microflora populations in our experiment. One of the effects of the fermentation of insulin-type fructans in the large bowel is a selective process; bifidobacteria (and possibly a few other genera) are preferentially stimulated to grow, thus causing significant changes in the composition of the gut microflora by increasing the number of potentially health-promoting bacteria and reducing the number of potentially harmful species, including $E$. coli and Clostridium [49]. Larrosa et al. [52] found that ellagitannins from pomegranate and theirs metabolites, urolithins, decreased enterobacteria and increased lactobacilli and bifidobacteria. Moreover, both ellagitannins and urolithins decreased inflammation markers (iNOS, cycloxygenase-2, PTGES and PGE2) in colonic mucosa of rats. Giménez et al. [23] also shown that it is the urolithins, the ellagitannins metabolites, not ellagitannins themselves have an effect in preventing vascular inflammation. Other authors also found that the urolithins are responsible for serum and liver lipids reduction [20, 21].

In this context, beneficial should seem the synergic with FOS inhibition of $\beta$-glucuronidase activity in intestinal digesta and increased production of SCFA in rat caecum by the PTW preparation. It is common knowledge that one of the mechanisms by which the intestinal microbiota may reduce Enterobacteriaceae (including Salmonella) is the bacteriostatic effect of short-chain fatty acids in the caeca [53].

In conclusion, both the sublimation-dried water extract and the alcohol extract from strawberry pomace showed a 
similar effect on the enzymatic activity of intestinal microflora in rats. An important effect of the application of both extracts in a diet was the reduction in the activity of $\beta$-glucuronidase in caecal digesta and in faeces, indicating positive changes in the population of intestinal microflora. It was a similar effect to that obtained by substituting dietary cellulose with more easily fermentable FOS. A lower content of proanthocyanidins $3.6 \%$ of the total polyphenols) and at the same time a higher content of the soluble carbohydrate fraction (together with dietary fibre constituting $76.1 \%$ of the extract) in the water extract resulted in an increased production of SCFAs in caecal digesta, compared to the water-alcohol extract. The application of water extract from strawberry pomace in the diets intensified the physiological effects of FOS, e.g. in inhibiting the activity of $\beta$-glucuronidase and the production of SCFAs in caecum, whilst no such an effect was induced by the water-alcohol extract being richer in proanthocyanidins (38\% of the total polyphenols).

Acknowledgments Supported in part by the Ministry of Science and Higher Education by the resources allocated for science in 2010-2013 under research project N N312 360 139. Supported in part by the Ministry of Science and Higher Education by the resources allocated for science in 2011-2012 under research project IP 2010 051870 'Iuventus project'.

Conflict of interest On behalf of all authors, the corresponding author states that there is no conflict of interest.

Open Access This article is distributed under the terms of the Creative Commons Attribution License which permits any use, distribution, and reproduction in any medium, provided the original author(s) and the source are credited.

\section{References}

1. Hansen L, Vehof H, Dragsted LO, Olsen A, Christensen J, Overvad K, Tjønneland A (2009) Fruit and vegetable intake and serum cholesterol levels; a cross-sectional study in the diet, cancer and health cohort. J Hortic Sci Biotechnol ISAFRUIT Special Issue:42-46

2. Schieber A, Stintzing FC, Carle R (2001) By-products of plant food processing as a source of functional compounds-recent developments. Trends Food Sci Technol 12:401-413

3. Kołodziejczyk K, Markowski J, Kosmala M, Król B, Płocharski W (2007) Apple pomace as a potential source of nutraceutical products. Pol J Food Nutr Sci 57:291-295

4. Kosmala M, Kołodziejczyk K, Zduńczyk Z, Juśkiewicz J, Boros D (2011) Chemical composition of natural and polyphenol-free apple pomace and the effect of this dietary ingredient on intestinal fermentation and serum lipid parameters in rats. J Agric Food Chem 59:9177-9185

5. Korus J, Juszczak L, Ziobro R, Witczak M, Grzelak K, Sójka M (2012) Defatted strawberry and blackcurrant seeds as functional ingredients of gluten-free bread. J Texture Stud 43:29-39

6. Klimczak E, Rozpara E, Król B (2011) Rozmieszczenie elagotanin $\mathrm{w}$ soku, miąższu i nasionach jako dodatkowe kryterium optymalnego zagospodarowania truskawek. Żywność Nauka Technologia Jakość 6:142-154

7. Sójka M, Król B (2009) Composition of industrial seedless black currant pomace. Eur Food Res Technol 228:597-605

8. Kosmala M, Kołodziejczyk K, Markowski J, Mieszczakowska M, Ginies C, Renard CMGC (2010) Co-products of black-currant and apple juice production: hydration properties and polysaccharide composition. LWT Food Sci Technol 43:173-180

9. Giampieri F, Tulipani S, Alvarez-Suarez JM, Quiles JL, Mezzetti B, Battino M (2012) The strawberry: composition, nutritional quality, and impact on human health. Nutrition 28:9-19

10. Wang SY, Zheng W, Galletta GJ (2002) Cultural system affects fruit quality and antioxidant capacity in strawberries. J Agric Food Chem 50:6534-6542

11. Ou HC, Lee WJ, Lee SD, Huang CY, Chiu TH, Tsai KL, Hsu WC, Sheu WH (2010) Ellagic acid protects endothelial cells from oxidized low-density lipoprotein-induced apoptosis by modulating the PI3 K/Akt/eNOS pathway. Toxicol Appl Pharmacol 248:134-143

12. Heber D (2008) Multitargeted therapy of cancer by ellagitannins. Cancer Lett 269:262-268

13. Hannum SM (2004) Potential impact of strawberries on human health. Crit Rev Food Sci Nutr 44:1-7

14. Gil MI, Tomas-Barberan FA, Hess-Pierce B, Holcroft DM, Kader AA (2000) Antioxidant activity of pomegranate juice and its relationship with phenolic composition and processing. J Agric Food Chem 48:4581-4589

15. Manach C, Williamson G, Morand C, Scalbert A, Rémésy C (2005) Bioavailability and bioefficiency of polyphenols in humans.I. Review of 97 bioavailability studies. Am J Clin Nutr 81(Suppl.):230S-242S

16. Cerdá B, Espín JC, Parra S, Martínez P, Tomás-Barberán FA (2004) The potent in vitro antioxidant ellagitannins from pomegranate juice are metabolised into bioavailable but poor antioxidant hydroxy-6H-dibenzopyran-6-one by the colonic microflora of healthy humans. Eur J Nutr 43:205-220

17. Truchado $\mathrm{P}$, Larrosa M, García-Conesa M-T, Cerdá B, VidalGuevara ML, Tomas-Barberan F, Espín JC (2012) Strawberry processing does not affect the production and urinary excretion of urolithins, ellagic acid metabolites, in humans. A cross-over study. J Agric Food Chem 60:5749-5754

18. Cerdá B, Tomás-Barberán FA, Espín JC (2005) Metabolism of antioxidant and chemopreventive ellagitannins from strawberries, raspberries, walnuts and oak-aged wine in humans: identification of biomarkers and individual variability. J Agric Food Chem $53: 227-235$

19. González-Barrio R, Truchado P, Ito H, Espín JC, Tomás-Barberán FA (2011) UV and MS identification of urolithins and nasutins, the bioavailable metabolites of ellagitannins and ellagic acid in different mammals. J Agric Food Chem 59:1152-1162

20. Aviram M, Rosenblat M, Gaitini D, Nitecki S, Hoffman A, Dornfeld L, Volkova N, Presser D, Attias J, Liker H, Hayek T (2004) Pomegranate juice consumption for three years by patients with carotid arterial stenosis reduces common carotid-media thickness, blood pressure and LDL oxidation. Clin Nutr 23:423-433

21. Larrosa M, García-Conesa MT, Espín JC, Tomás-Barberán FA (2010) Ellagitannins, ellagic acid and vascular health. Mol Aspects Med 31:513-539

22. Jaroslawska J, Juskiewicz J, Wroblewska M, Jurgowski A, Krol B, Zdunczyk Z (2011) Polyphenol-rich strawberry pomace reduces serum and liver lipids and alters gastrointestinal metabolite formation in fructose-fed rats. J Nutr 141:1777-1783

23. Giménez JA, González-Sarrías A, Larrosa M, Tomás-Barberán FA, Espín JC, García-Conesa MT (2012) Ellagitannin metabolites, urolithin A glucuronide and its aglycone urolithin A, 
ameliorate TNF- $\alpha$-induced inflammation and associated molecular markers in human aortic endothelial cells. Mol Nut Food Res 56:784-796

24. Juskiewicz J, Zdunczyk Z (2004) Effects of cellulose, carboxymethylcellulose and inulin fed to rats as single supplements or in combinations on their caecal parameters. Comp Biochem Physiol 139A:513-519

25. Horwitz W, Latimer GW (2007) Official methods of analysis of AOAC International, 18th edn 2005. AOAC International, USA

26. Kennedy JA, Jones GP (2001) Analysis of proanthocyanidin cleavage products following acid-catalysis in the presence of excess phloroglucinol. J Agric Food Chem 49:1740-1746

27. Reeves PG (1997) Components of the AIN-93 diets as improvements in the AIN-76A Diet. J Nutr 127:838S-841S

28. Juśkiewicz J, Zduńczyk Z (2002) Lactulose-induced diarrhea in rats: effect on caecal development and activities of microbial enzymes. Comp Biochem Physiol 133A:411-417

29. Hofirek B, Haas D (2001) Comparative studies of ruminal fluid collected by oral tube or by puncture of the caudorental ruminal sac. Acta Vet Brno 70:27-33

30. Aaby K, Skrede G, Wrolstad RE (2005) Phenolic composition and antioxidant activities in flesh and achenes of strawberries (Fragaria ananassa). J Agric Food Chem 53:4032-4040

31. Määttä-Riihinen KR, Kamal-Eldin A, Törrönen AR (2004) Identification and quantification of phenolic compounds in berries of Fragaria and Rubus species (family Rosaceae). J Agric Food Chem 52:6178-6187

32. Landete JM (2011) Ellagitannins, ellagic acid and their derived metabolites: a review about source, metabolism, functions and health. Food Res Int 44:1150-1160

33. Kähkönen MP, Hopia AI, Heinonen M (2001) Berry phenolics and their antioxidant activity. J Agric Food Chem 49:4076-4082

34. Buendía B, Gil MI, Tudela JA, Gady AL, Medina JJ, Soria C, López JM, Tomás-Barberán FA (2010) HPLC-MS analysis of proanthocyanidin oligomers and other phenolics in 15 strawberry cultivars. J Agric Food Chem 58:3916-3926

35. Da Silva Pinto M, Lajolo MF, Genovese MI (2008) Bioactive compounds and quantification of total ellagic acid in strawberries (Fragaria x ananassa Duch.). Food Chem 107:1629-1635

36. Oszmianski J, Wojdyło A, Kolniak J (2009) Effect of L-ascorbic acid, sugar, pectin and freeze-thaw treatment on polyphenol content of frozen strawberries. LWT Food Sci Technol 42:581-586

37. Hakkinen SH, Törrönen AR (2000) Content of flavonols and selected phenolic acids in strawberries and Vaccinium species: influence of cultivar, cultivation site and technique. Food Res Int 33:517-524

38. Oszmiański J, Wojdyło A, Matuszewski P (2007) Zmiany zawartości związków fenolowych podczas produkcji zagęszczonego soku truskawkowego w warunkach przemysłowych. Żywność Nauka Technologia Jakość 1:94-104

39. Rios LY, Bennett RN, Lazarus SA, Remesy C, Scalbert A, Williamson G (2002) Cocoa procyanidins are stable during gastric transit in humans. Am J Clin Nutr 76:1106-1110
40. Holt RR, Lazarus SA, Sullards MC (2002) Procyanidin dimer B2 (epicatechin-(4- $\beta-8)$-epicatechin) in human plasma after the consumption of flavanol-rich cocoa. Am J Clin Nutr 76:798-804

41. Beecher GR (2004) Proanthocyanidins: biological activities associated with human health. Pharm Biol 42:2-20

42. Rios LY, Gonthier MP, Remesy C, Mila I, Lapierre C, Lazarus SA, Williamson G, Scalbert A (2003) Chocolate intake increases urinary excretion of polyphenol derived phenolic acids in healthy human subjects. Am J Clin Nutr 77:912-918

43. Lhoste EFL, Nugon-Baudon S, Lory J-C, Meslin C, Andrieux C (2001) The fermentation of lactulose in rats inoculated with Clostridium paraputrificum influences the activities of liver and intestinal xenobiotic-metabolism enzymes. J Sci Food Agric 81:1397-1404

44. Goñi IT, Jiménez-Escrig A, Gudiel M, Saura-Calixto FD (2005) Artichoke (Cynara scolymus L) modifies bacterial enzymatic activities and antioxidant status in rat cecum. Nutr Res 25:607-615

45. Pool-Zobel B, van Loo J, Rowland I, Roberfroid MB (2002) Experimental evidences on the potential of prebiotic fructans to reduce the risk of colon cancer. Br J Nutr 87(Suppl. 2):273-281

46. Negi PS, Jayaprakasha GK (2001) Antibacterial activity of grapefruit (Citrus paradisi) peel extract. Eur Food Res Technol 213:484-487

47. Zduńczyk Z, Juśkiewicz J, Estrella I (2006) Cecal parameters of rats fed diets containing grapefruit polyphenols and inulin as single supplements or in a combination. Nutrition 22:898-904

48. Aprikian O, Duclos V, Guyot S, Besson C, Manach C, Bernalier A, Morand C, Remesey C, Demigne C (2003) Apple pectin and a polyphenol-rich apple concentrate are more effective together than separately on caecal fermentation and plasma lipids in rats. J Nutr 133:1860-1865

49. Roberfroid MB (2005) Introducing inulin-type fructans. Br J Nutr 93:13-25

50. Jurgonski A, Juskiewicz J, Zdunczyk Z (2008) Comparative effects of different dietary levels of cellulose and fructooligosaccharides on fermentative processes in the caecum of rats. J Anim Feed Sci 17:88-99

51. McBain AJ, Macfarlane GT (1998) Ecological and physiological studies on large intestinal bacteria in relation to production of hydrolytic and reductive enzyme involved in formation of genotoxic metabolites. J Med Microbiol 47:407-416

52. Larrosa M, González-Sarrías A, Yáñez-Gascón MJ, Selma MV, Azorín-Ortuño M, Toti S, Tomás-Barberán FA, Dolara P, Espín JC (2010) Anti-inflammatory properties of a pomegranate extract and its metabolite urolithin-A in a colitis rat model and the effect of colon inflammation on the phenolic metabolism. J Nutr Biochem 21:717-725

53. van der Wielen PW, Biesterveld S, Notermans S, Hofstra H, Urlings BA, van Knapen F (2000) Role of volatile fatty acids in development of the cecal microflora in broiler chickens during growth. Appl Environ Microbiol 66:2536-2540 